\section{ABUSE OF MEDICAL CHARITY.}

To the Editor of THE LANCET.

SIR,-A good deal has been written of late concerning the abuse of medical charity. In many instances this abuse has been perpetrated in such a manner as to put the control of it beyond the power of medical men themselves, as, for instance, that which takes place in the out-patient rooms of our large hospitals, \&c. Some cases, however, appear to be connived at by our confrères, as in the following instance, and I should be very glad to have your opinion on it.

A patient of mine has just been spending a month at $\mathrm{W}-$. She is a retired shopkeeper, and in very comfortable circumstances, perfectly able to pay me (her medical attendant) $\mathrm{my}$ bill as soon as it is delivered. In fact, her means may be judged of by anyone who considers that she was residing, for her own pleasure, at the seaside for a month in the height of the season. On my seeing her on her return, she told me she had been under the care of Dr. - - as an out-patient at the W- Sanatorium. She told me with considerable satisfaction that "it was all gratis, and she had just as good advice as if she had called at Dr. - 's house and paid a guinea for it." I asked her if any questions were asked as to her circumstances, \&c. She said, No, and added that "there were some of the patients that appeared quite ladies and gentlemen, and one young man brought his sister, who had a gold brooch and locket and a gold watch and chain."

Now, Sir, the consequence is this. My patient brings with her a prescription from this sanatorium, by which she goes on taking medicine made up by her druggist, instead of again putting herself under my care. I see that the $W$ - Sanatorium is founded for the relief of "diseases peculiar to women and children." Whether the medical officers consider diabetes (such is my patient's malady) to come under that category I know not; but I should like to ask you, Sir, whether you think the abuse of medical charity can be carried much farther than in the case I mention. I asked my patient how she heard of this charming charitable institution? She said she heard of it from a lady with whom she became acquainted by sitting reading near one another on the beach, and who strongly impressed upon her the advantages (particularly pecuniary) to be derived from an attendance at its out-patient department.

Cirencester, Sept. 8th, 1875 .

$$
\text { I remain, Sir, yours obediently, }
$$
Edward Cripts.

\section{BIRMINGHAM.}

(From our own Correspondent.)

THE medical education of women question is now causing great public excitement in this town. An influential deputation, headed by the Mayor, and including Dr. Heslop, and Messrs. Furneaux Jordan and C. J. Bracy as medical representatives, attended the last meeting of the Council of Queen's College, and strongly urged the desirability of provision being made at the College for the teaching of women students. The Mayor assured the Council that the introduction of female students would popularise the College, and that the deputation would be prepared to overcome any financial or other difficulties that might arise to prevent the realisation of their wishes. Dr. Heslop pointed out that at present ladies were obliged to go to Paris, Zurich, or America for a medical education, and that, as the general public had come to the conclusion that those women who persisted in undergoing a medical training should have an opportunity of doing so in England, it was better that the education should be given in a school like that of Birmingham, which had a reputation, recognition from the Medical Council, and all the machinery for giving a good medical education, rather than that a new educational institution for the special use of women should be started. The Rev. C. Clarke, as chairman of the Queen's Hospital Committee, expressed his belief that there was public spirit enough on the part of the board to meet, if possible, the views of the deputation, and to prevent any difficulty being thrown in the way of the admission of women to the hospital, provided the Council of Queen's College would themselves accept their co-operation. After a long discussion, an understanding seemed to be arrived at that the assent of the hospital authorities must be obtained, and that the deputation must be prepared to guarantee the College a sufficient amount to cover the fees in those cases in which the Professors declined to lecture to double classes.

Dr. Richardson's success as a popular lecturer is so well known that one was not surprised at the large audience that assembled to hear his lecture on "Tobacco in relation to Health." The Midland Institute have wisely secured his services, as well as those of Dr. Ferrier, for lectures on physiological subjects during the ensuing session.

The medical profession in Birmingham have to deplore the death of Dr. Alexander Fleming, late Physician to the Queen's Hospital, at the comparatively early age of fifty. one. He had been in practice here about eighteen years, and during that time had acquired a high and well-deserved reputation as an exact and careful physician, and as a therapeutist of great skill. His kindliness and patience as a clinical teacher made him respected and beloved by all pupils, and his courtesy and ability secured for him the esteem and regard of a large circle of professional as well as private friends. Dr. Fleming died from chronic renal disease. Death has also been busy among the younger members of our body. Mr. E. B. Ravenhill, late housesurgeon to the General Hospital, Wolverhampton, died suddenly at the age of twenty-five, from syncope, after a few dajs' suffering, with symptoms of gastro-intestinal catarrh, the effect in all probability of overwork. Mr. J. T. Smith, of Sutton Coldfield, has also died quite suddenly, while in the full vigour of manhood. He had been, like Mr. Ravenhill, a distinguished student of Queen's College, and he had subsequently held the appointments of housesurgeon to the Lying-in Hospital and resident medical officer at the Birmingham Dispensary.

The Medical Institute is said to be making good progress. Two hundred volumes have already been presented, and a "local habitation" is about to be secured to give room for further gifts and purchases.

The necessary arrangements are being made for Hospital Sunday. 'The appeal from the pulpits will be made on Oct. 31st, and will be on behalf of the Queen's Hospital.

Diarrhœa is very prevalent, but in other respects the town is healthier than usual at this season of the year.

Birmingham, Sept. 20 th, 1875 .

\section{NEWCASTLE - ON - TYNE. (From our own Correspondent.)}

WE boast of a Vegetarian Society here, and the other night it gave a grand banquet in furtherance of its principles. It was very numerously attended by ladies and gentlemen. The menu was as follows:-Vegetarian pie, vegetable marrow stuffed with fried potatoes, potatoes roasted, potatoes mashed, haricot beans and parsley sauce, English beans, English peas, tomatoes, onions boiled, onions roasted, boiled lentils, plain pudding, rice pudding, sago pudding, mixture of apples and preserved stewed apples, and stewed pears. Numerous enthusiasts in the vegetarian's régime were constantly explaining the qualities of the various dishes. The majority of the guests seemed undoubtedly to enjoy the banquet, but to many a sigh of relief involuntary came when the cooked dishes were removed and the dessert fruit was placed upon the table. A public meeting was afterwards held to promote vegetarian views, and the com. pany separated on the whole well pleased with their harmless experiment.

The ancient and picturesque little town of Chester-lestreet, with its historical castle at Lumley and interesting church so rich in sculptured monuments of knights and crusaders, used to be a favourite drive from Newcastle and Gateshead, and its neighbouring slopes attractive resorts for pic-nic and other excursion parties; but latterly the good old town has literally fallen into "bad odour" with all health and pleasure seekers, and travellers for some time past have been fain to give it the "go by," and endeavour to reach their destination by circuitous routes rather than 